digested it the student should throw it away. This advice is, of course, not required by the exceptional student who has learned how to use a library and reads for interest rather than out of fear of failure.

The large reference textbook requires little consideration. The good ones approximate to a collection of monographs and can be judged by the same standards.

What, then, is the place of this new textbook? As an authoritative work of reference it can be dismissed. There is no discussion of evidence and there are no references. Only Americans attempt to provide such books covering the whole of medicine. I doubt if they will do it for much longer and the field will then be left to monographs.

This book must then be judged as an alternative to the several 'students' textbooks.

Can a student read it? Yes, it is very legible and at five minutes per page it will only take 40 hours (one month at two hours a night, five nights a week).

Is it accurate? My sampling detected no statement to which, as an examiner, I would take exception.

Is it up to date? My sampling suggested that it gave a very good account of medicine as practised in and around London in 1960.

Is it illustrated? Yes. There are a few good line drawings and about 30 plates, mostly radiographs, which are well chosen, beautifully produced, probably expensive and educationally pointless.

Is it well produced? Yes, the shape and size are pleasant, it lies open and the print is clear. I found few printer's errors.

How does it differ from its competitors? Dr. Todd is out of sympathy with the teaching of medicine as a series of disease entities usually defined in terms of morbid anatomy. This is apparently the way medicine was taught before the war and the way most textbooks are still written, even by doctors who do not personally teach students this way any more. He also dislikes evidence based on a priori speculation. He certainly tilts at some well-known windmills and most of the contributors avoid these sins as far as is compatible with telling a story. Even so, there are many unqualified statements in fields where knowledge is limited which could be questioned.

Is it worth the money? It is certainly more expensive than some of its competitors, but it is more detailed and up to date than most.

Is it likely to interest the postgraduate? Yes, it should be good for the membership.

\section{Memories of a Doctor in War and Peace}

Isabel HutTon, C.B.E., M.D. Pp. 348. London: William Heinemann. 1960. 25s.

This is the latest work by Lady Hutton, wife of Lieut.-General Hutton, K.C.I.E., C.B., M.c. It is part of the irony of Fate that this talented author, whose writings must have given so much help and encouragement to so many of her fellow creatures, should have died (in January 1960) before she could have the joy and pride of seeing her last literary creation upon the bookstalls. This volume, which tells the story of her early life, her education and qualification as a Doctor of Medicine in the University of Edinburgh, and her subsequent life of public work, has been published by her executors. It makes excellent reading, for her style is clear and attractive. The book is full of interesting and illuminating details from start to finish, and gives the reader an inspiring picture of one who had a very real and genuine call to medicine and to a life of service. In the earlier part of the book she gives a fascinating account of many well-known teachers of the Edinburgh medical school, made all the more delightful by the frequent touches of humour by which it is enlivened, and which moreover show the author's insight and power of understanding and human sympathy. These inborn characters are equally apparent in the later chapters, which deal with her postgraduate appointments and her subsequent career in both the world wars as well as in the intervening period, during much of which she worked in India.

This work should make a strong appeal to readers who like history and who can appreciate the importance of character and personality in members of the medical profession. The book is one which we recommend especially to busy people who need some holiday reading. It is sufficiently light to afford relaxation, but it contains so much that is well worth study and careful consideration.

\section{Principles of General Neuro-Physiology Relating to Anzesthesia and Surgery}

BARRy D. WyKe, M.B., B.s. Pp. $x+136$, illustrated. London: Butterworth. 1960. 2 Is.

This is a reprinting of chapter 5 , volume $I$, of ' General Anæsthesia' edited by Evans and Gray, and published by Butterworth in 1959. Although there are said to be minor modifications, the text appeared to the reviewer to be identical with the original. The book is a clearlywritten, up-to-date essay on certain aspects of neurophysiology, largely at the cellular level; many of the problems of integration and disintegration of the nervous system-pain, memory, and even consciousness itself, do not come within the author's self-chosen compass.

Although easy to read, the text is rendered almost valueless to the serious student by a persistent failure to attribute specific statements and findings to specifies authors. Admittedly there is a bibliography at the en of each section, but what is the use of references, as Alice might have said, unless one knows precisely to what they refer. The continual repetition of statements like "there is considerable evidence'; ' modern anatomical and physiological research has shown' and ' further details are available in relevant special works' becomes tedious and irritating; similarly, the only guide to the complication of several of the tables is the bald statement ' average of values from various sources'. Equally inconvenient is the lack of an index, for which the justification that "this would increase the size of the book unduly' seems particularly lame.

To many anæsthetists, the principal bone of contention will be the author's unbridled enthusiasm for electro-encephalographic monitoring of anæsthesia. In fact although the E.E.G. may be of value during deep anæsthesia, it has proved singularly uninformative as a measure of amnesia or the onset of unconsciousness. Clutton-Brock's study of photic stimulation under nitrous oxide is not quoted, and although the bibliography contains an early reference to Bellville and Artusio, their work is not discussed in the text.

On the whole, this is a good-looking but rather disappointing book.

Regulation of the Inorganic Ion Content of Cells CIBA Foundation Study Group No. 5. Editors: G. E. W. Wolstenholme and C. M. O'ConNor. Pp. viii + roo. London: J. \& A. Churchill. I960. I2s. $6 d$.

This slim volume reports the proceedings of a study group in honour of Professor E. J. Conway, who might be said to be the founder of the subject. The first paper is by the guest of honour himself, who later takes part in the discussions. The other five contributions 